\author{
Alicja Korzeniecka-Bondar \\ Uniwersytet w Białymstoku \\ E-MAIL: alibon@uwb.edu.pl
}

\title{
Akademickie teraźniejszości
}

1) Pracować szybko i wydajnie, 2) być menadżerem swojej kariery, zdobywając terminowo kolejne szczeble awansu, 3) prowadzić badania w obszarach istotnych z perspektywy rozwoju gospodarczego, pozyskując zewnętrzne środki, 4) publikować jak najwięcej tekstów (najlepiej w wysoko punktowanych czasopismach), 5) bezwzględnie dążyć do indywidualnych celów, 6) nie oglądać się na innych, nie dzielić wiedzą, 7) być gotowym do realizacji różnorodnych zajęć dydaktycznych (nawet każdego roku innych), 8) umiędzynarodawiać proces dydaktyczny, 9) być atrakcyjnym, miłym i pomocnym dla studentów, bez względu na ich liczbę i stosunek do uczenia się, 10) organizować liczne inicjatywy na rzecz własnej jednostki oraz instytucji zewnętrznych o różnym zasięgu.

Tak brzmią „prawa” panujące obecnie w rzeczywistości akademickiej. Ironiczny ton powyższej wypowiedzi jest próbą zdystansowania się wobec owych „praw”, coraz bardziej zawłaszczających funkcjonowanie pracowników uczelni. Nawet gdy nie są one wprost zwerbalizowane w aktach prawnych czy zewnętrznych oczekiwaniach, to wyczuwamy je niemalże intuicyjnie $\mathrm{i}-\mathrm{w}$ mniejszym lub większym stopniu - podporządkowujemy im swoje codzienne działania. Jednak gdyby na ich podstawie sformułować pytania (np. czy chciałbyś pracować szybko i wydajnie, czy z namysłem i tak długo, jak wymaga tego zadanie?) i pozwolić osobie wybierać, to pewnie znakomita większość opowiedziałaby się za zupełnie innym wizerunkiem pracy na uczelni. Można go sprowadzić do kilku reguł: dąż do tworzenia wartościowej wiedzy o świecie; pisz wtedy, gdy masz coś ważnego do powiedzenia; łącz rezultaty badań naukowych z zajęciami dydaktycznymi; stawiaj studentom zadania rozwojowe; organizuj wydarzenia mające znaczenie i potrzebne dla rozwoju własnego i innych; dbaj o jakość swojego czasu wolnego i realizowanych pasji. 
Przygotowujemy numer „Parezji”, gdy toczy się dyskusja nad kształtem ustawy o szkolnictwie wyższym, zawierającej zapisy praw i obowiązków akademików. Są środowiska oczekujące proponowanych zmian, ale i takie, które się ich obawiają, choć podejmują starania dostosowania się do wymagań. Dla niektórych planowane zapisy oznaczają całkowite zniknięcie $\mathrm{z}$ akademickiej mapy Polski. Trudno mówić o modelowej uczelni, której opisanie pozwoliłoby odpowiedzieć na pytanie: co dzieje się obecnie na uczelni i z uczelnią? Inaczej mówiąc - akademickich teraźniejszości jest tyle, ile środowisk je tworzących. Codzienne funkcjonowanie pracowników uczelni jest oscylowaniem między, nakreślonymi powyżej, skrajnymi wizerunkami, każdodniowym wyborem wartości, za którymi się opowiadamy. Czytelnikom pozostawiamy decyzję, jaką uczelnię, na jakich wartościach budowaną, chcą współtworzyć swoją pracą.

Przedkładany numer jest zarówno próbą diagnozy obecnego stanu funkcjonowania uczelni, jak i artykułowaniem tego, co jest ważne dla Autorów poszczególnych tekstów. Stanisław Gajda w tekście pt. JęZYK w NAUCE ( $w$ PERSPEKTYWIE FILOZOFICZNO-LINGWISTYCZNEJ) wskazuje na znaczenie języka w budowaniu teorii. Czytelnik znajdzie tu dwie części: pierwszą - poświęconą teorii naukowej, drugą - dotyczącą komunikacji w nauce. Autor zwraca uwagę, że „teoria języka musi przyjąć, iż język nie tylko wyraża to, co w umyśle i komunikuje innym, lecz także kształtuje ludzkie myślenie i oddziałuje na obiektywną rzeczywistość. Język w nauce jest determinowany przez kontakt społeczno-kulturowy (tradycję) oraz kontekst komunikacyjny, ale na jego kształt ma też wpływ indywidualne, podmiotowe poczucie stylowe". Tekst ten stanowi zaadaptowaną do druku wersję referatu wygłoszonego w trakcie XXXI Letniej Szkoły Młodych Pedagogów (LSMP), odbywającej się w tym roku w Warszawie (o czym szerzej w Sprawozdaniu). Profesor zgodził się dokonać tego opracowania specjalnie na rzecz „Parezji”, za co w imieniu własnym i wszystkich Czytelników serdecznie dziękuję. Z radością zapowiadam, że to niejedyna wypowiedź „przechwycona” w trakcie LSMP, dotyczącej problematyki pisarstwa.

Tekst Marty Kowalczuk-Walędziak pt. KILKa uWAG o (ROz)ŁĄCZnośCI DZIAŁALNOŚCI BADAWCZEJ I DYDAKTYCZNEJ NAUCZYCIELA AKADEMICKIEGO wpisuje się - co stwierdza jeden $\mathrm{z}$ recenzentów - w debatę dotyczącą reformowania szkolnictwa wyższego i zmian w zakresie karier akademickich, zwłaszcza propozycji zróżnicowanych ścieżek kariery, w tym ścieżki naukowej i dydaktycznej. Autorka ukazała, w świetle dostępnej literatury przedmiotu, różne aspekty (odrębności i związki) działalności badawczej i dydaktycznej nauczyciela akademickiego, a także korzyści wynikające z łączenia obu tych obszarów. 
Zaprezentowała model powiązań między badaniami naukowymi i działalnością dydaktyczną w programach kształcenia akademickiego w ujęciu M. Healeya.

Przeglądu wybranych wyzwań polskiego szkolnictwa wyższego dokonał Cezary Kościelniak. Autor stawia tezę, że polskie uniwersytety, przechodzące od lat szereg reform, wciąż pozostają w tyle za uczelniami państw wysokorozwiniętych. Wskazuje na wybrane bariery w rozwoju polskich uczelni, do których zalicza: problem przywództwa, spór o kształt misji uniwersytetu, problemy umiędzynarodowienia oraz kwestie kulturowo-etyczne. Szerokiej analizy uniwersytetu i jego współczesnych przemian dokonuje filozof Małgorzata Kowalska w rozmowie z Alicją Korzeniecką-Bondar, stwierdzając, że jest on w ryzach myślenia technokratyczno-biznesowego. Kurczy się autonomia uniwersytetu jako miejsca swobodnej dyskusji, rozwijania horyzontów, poszerzania i zdobywania wiedzy. Obecnie staje się on coraz bardziej podporządkowany bieżącym interesom politycznym i ekonomicznym oraz zaprzęgnięty do wyścigu gospodarczo-technologicznego i rynkowego. $\mathrm{Na}$ konsekwencje takiego stanu rzeczy wskazują Marzanna Morozewicz i Dorota Świdzińska. Te czynne artystki ukazują, w rozmowie z Joanną Sacharczuk, trudną sytuację zawodową twórców zatrudnionych na wydziałach nieartystycznych. Wynika ona $\mathrm{z}$ faktu, że ich dokonania artystyczne nie podlegają ocenie parametrycznej. Podkreślają, że artysta komunikuje się ze światem innym językiem niż naukowiec i nie można go zmuszać, by przemawiał nieswoim głosem. Dorobek artystów, w świetle obecnych przepisów, jest na wydziałach nieartystycznych deprecjonowany, co wpływa nie tylko na kształt ich kariery, ale także na jakość życia.

Ścieżką własnej twórczości - tym razem poetyckiej - poprowadzi Czytelnika profesor Andrzej Góralski. Wszyscy, którzy znają profesora jako znakomitego matematyka, metodologa oraz teoretyka twórczości i heurystę, zdziwić się mogą, że uczy także, jak pisać poezję. Ta nauka skierowana była do uczestników XXXI Letniej Szkoły Młodych Pedagogów. Po przejmującym warsztacie zwróciłam się do profesora z (nierealną - jak mi się wówczas wydawało) propozycją, by zgodził się opublikować swój tekst w „Parezji”. Zaproszenie przyjął z nieukrywaną radością, czym i mnie ją sprawił. Chciałoby się zawołać: tylko u nas piękne i przenikliwe wiersze profesora Góralskiego, lecz to trąca targiem. Posłużę się zatem słowami Autora: „[p]roszę więc - niechaj każdy weźmie stąd to, co uzna za ważne oraz przydatne".

Dla podejmujących się badań w strategii badań jakościowych polecam wypowiedź Jolanty Sajdery dotyczącą konstruowania problematyki badań nad edukacją. Autorka wskazała możliwości zastosowania koncepcji konstruktów myślowych Alfreda Schütza podczas wyznaczania przez badacza 
obszaru problemowego, ujętego w strukturę pytań pierwszego i drugiego stopnia. Omówiła także pułapki w podejmowaniu decyzji badawczych, ale także potencjalne korzyści płynące $\mathrm{z}$ ich doświadczenia.

Alicja Korzeniecka-Bondar uwrażliwia na błędy popełniane przez niektórych Autorów piszących do „Parezji”, omawiając kilka ich grup: poznawcze, strukturalne, pragmatyczne, stylistyczne i formalne.

Na uwagę Czytelników zasługują studia recenzyjne przygotowane przez Oskara Szwabowskiego i Piotra Stańczyka. Pierwszy z nich dokonał analizy książki Reconceptualizing Study in Educational Discourse and Practice (edited by Claudia W. Ruitenberg, Routledge 2017). Recenzowany tom pomyślany jest, co ujmuje Szwabowski, jako „szukanie innych sposobów myślenia i praktykowania edukacji niż dominująca praktyka i ideologia „edukacji opartej na dowodach", która sprowadza działanie pedagogiczne do społecznej inżynierii (Ruitenberg, 2017, s. 3)". Na marginesie dodam, że książkę tę wydawnictwo Routledge nieodpłatnie przekazało na rzecz recenzującego, dzięki staraniom redakcji „Parezji”. Piotr Stańczyk dokonał recenzji pracy Co to ZA GRA? Nowe PODEJŚcia do eKonomiI (Warszawa: Książka i Praca, 2017) autorstwa brazylijskiego ekonomisty Ladislaua Dowbora. Recenzja napisana jest z perspektywy pedagogicznej, a uwarunkowania ekonomiczne uznane są za kluczowe dla procesów edukacyjnych w ogóle, a w szczególności dla procesów edukacyjnych zorientowanych emancypacyjnie.

Interesującym wydarzeniem, sprawozdanym przez Anetę Makowską i Maksymiliana Chutorańskiego, jest I Ogólnopolska Interdyscyplinarna Konferencja Naukowa o wymownym tytule: Pedagogika Rzeczy. Rzeczy W PROCESACH EDUKACYJNYCH I ICH KONTEKSTACH, która odbyła się w maju 2017 r. w Szczecinie. Celem konferencji - o czym Czytelnik dowie się ze sprawozdania - było uruchomienie szerokiej dyskusji dotyczącej miejsca materialności w procesach edukacyjnych i ich kontekstach.

Ważnym dla członków Forum Młodych Pedagogów wydarzeniem była - omówiona przez Macieja Ciechomskiego - XXXI Letnia Szkoła Młodych Pedagogów, poświęcona Problemom z WŁasnym lub Cudzym warsztatem PISARSTWA NAUKOWEgo. Kierownikiem naukowym Szkoły, po raz dwudziesty czwarty, była profesor Maria Dudzikowa, a gospodarzem Uniwersytet Kardynała Stefana Wyszyńskiego w Warszawie.

Tom zamyka List RedaKtorów NACZELnYCH CZASOPISM NAUKOWYCH wydawanych pod patronatem Komitetu Nauk Pedagogicznych PAN Do PosŁów Sejmu RP. Przygotowany w październiku 2017 r., stanowi wyraz niezgody na projekt likwidacji dotychczas obowiązującej Części B Wykazu czasopism punktowanych Ministerstwa Nauki i Szkolnictwa Wyższego. 